\title{
The Rise of China: Continuity or Change in the Global Governance of Development? \\ Catherine Weaver*
}

he global financial crisis of 2008 was a reflection point for global
economic governance. The crisis, which started in the U.S. banking sys-
tem and had a disproportionate impact on North America and Europe, provoked widespread contemplation of the legitimacy, relevance, and effectiveness of the core ideas, rules, and structures that have governed the world economy over the past century. In turn, the crisis also illuminated the emergence of new players, power dynamics, and paradigms that promise to challenge-if not fundamentally change-the characteristics of the institutional architecture that has governed international finance, trade, and development since the end of World War II.

Complex crises such as the global financial crisis and the ongoing Eurozone crisis can in fact spur dramatic change in global governance, leading to new rules-and rulers-to manage the formal and informal institutions of the world economy. Yet pervasive uncertainty, risks, vested interests, ideological dogmatism, and sheer inertia in institutions can drive governance more in the direction of modest adaptation than deeper reforms or transformation. Outcomes are not predetermined by any structural or ideational factor, but are rather an often unpredictable result of myriad variables, shaped by path dependency and contingency, that leave predictions less a science than an art. Scholars of global governance nonetheless have a responsibility to critically assess such patterns of continuity and change to both explain what is currently unfolding in the context of the longue durée and to make educated guesses about the future.

${ }^{\star}$ I would like to thank Lillian Leone and Sam Karnes for their research assistance on this essay.

Ethics \& International Affairs, 29, no. 4 (2015), pp. 419-431.

(C) 2015 Carnegie Council for Ethics in International Affairs

doi:10.1017/So892679415000404 
Manuella Moschella and I have offered three observations on global economic governance that propose how we might begin to make sense of the complexity of institutional continuity and change. ${ }^{1}$ First, over the past decade there has been a clear proliferation in the number of institutions designed to govern various aspects of the global economy. Second, within extant institutions there has been a tremendous growth in membership, leading to larger institutions facing the inevitable collective action problems that come with such expansion. Third, an increased variety of authorities from the private, public, and nonprofit sectors leads us to more critically question who are the key actors driving global governance. To this list I might add that the world today is experiencing more contested multilateralism than ever before, suggesting that we are observing-and may increasingly observe-countries leaving institutions, exercising their voice within international governmental organizations in more assertive ways, or even creating alternative international organizations and forums to pursue new policies and practices. $^{2}$

In order to make sense of these shifts, and to discern whether they will result in continuity or genuine change, we developed a heuristic frame to study the dynamic of global economic governance based on the mutually constitutive roles of three "Ps": players, power, and paradigms. This framework allows us to parse out continuity and change in global economic governance by focusing on shifts in the key actors (states, international institutions, or other nonstate actors), power (both material and ideational), and paradigms (the schools of thought that dictate what theories, policies, or practices are optimal or permissible in governance).

This essay explores one case of what I see as a possible critical juncture in the governance of international development that deals with shifts in all three Ps: the rise of China as a new aid donor. China, exercising its vast material power, is rapidly becoming a top lender in the bilateral field, and it is asserting its alternative ideas on aid funding and development cooperation. The recent establishment of several new Chinese-led development institutions, introducing new competition into the now crowded landscape of donors fighting for their own relevance and legitimacy, transforms the field of development into one of contested multilateralism. What may this rise of China mean for the global governance of development?

\section{Rising China in International Aid}

The dramatic growth of China's aid abroad has led many to wonder if it is trying to create an alternative global economic order to the U.S.-dominated postwar 
Bretton Woods system. Despite the lack of transparency in official statistics, estimates of overall Chinese annual development financing over the past five years exceed the lending of the major multilateral development banks established in the twentieth century. More recently, the failure to enact major governance reforms at the International Monetary Fund (IMF) and World Bank contributed directly to China's creation of two new multilateral development banks, the New Development Bank and the Asian Infrastructure Investment Bank. These institutions have carved out a clear comparative advantage in investing in infrastructure projects in developing countries, especially those in South Asia and Africa, which has accentuated the perception that the legitimacy and relevance of U.S.-dominated financial institutions are waning, as is the influence that the United States has exercised through these institutions for the past seventy-five years.

\section{Overview of Chinese Development Lending}

Determining how much development assistance China provides today is extremely challenging. Beyond the basic issue of lack of transparency, China defines development assistance quite differently from the Organisation for Economic Co-operation and Development's (OECD) Development Assistance Committee, reflecting a different paradigm of development "aid." China includes as aid many forms of investment that would normally fall outside the stricter definition of Official Development Assistance, promoting the idea of "financial partnerships" with borrower governments. Specifically, many of China's programs do not meet the OECD's requirements of a grant element of 25 percent. Moreover, lending policies at the China Development Bank (CDB) and Export-Import Bank (Eximbank) openly reject the OECD's discouragement of tied aid, and require that at least 50 percent of all goods purchased for foreign aid programs be of Chinese origin. Beijing's official statistics also blur the distinctions among aid commitments, disbursements, and expenditures. These policies complicate calculations of net flows, frequently leading to overestimates of actual spending by deriving numbers from "promised" aid. ${ }^{3}$ Given that China does not report to any major international database (such as the OECD Creditor Reporting System or the International Aid Transparency Initiative), the best independent estimates of China's aid are collated from secondary sources. One estimate is that Chinese development financing may be upward of 3 percent of China's reported gross domestic product, with a 
dramatic increase in annual spending from $\$ 1.7$ billion in 2001 to $\$ 189$ billion in $2011{ }^{4}$

Chinese bilateral development finance is primarily delivered through two of its policy banks, the CDB and Eximbank. The China Development Bank was established in 1994 and provides large-scale, long-term financing for infrastructure and industrial projects to break "strategic bottlenecks in energy, natural resources, and transportation created by China's rapid economic growth." ${ }^{5}$ It works under the guidance of China's State Council, but also exercises significant autonomy. ${ }^{6}$ At the end of 2010, the CDB had $\$ 687.8$ billion in loans on its books, more than twice as much as the World Bank that same year. It currently holds $\$ 100$ billion in capital and has over $\$ 1$ trillion in assets.

The Export-Import Bank was also established in 1994 to promote foreign trade and investment through export credits (mainly in infrastructure), but it also provides development assistance both within China and abroad through concessional loans. Now the world's largest export-credit institution, Eximbank is active in supporting Chinese construction and infrastructure in Africa, South America, and Asia, and on occasion it engages in joint financing with the World Bank.

Both the CDB and Eximbank have played central roles in China's "going out" policy over the last decade, dedicating an increasing portion of their loans to overseas investments, especially in the energy sector. ${ }^{7}$ For example, both have provided more than $\$ 200$ billion in lines of credit, commitments, and loans to Africa and Latin America. Kevin Gallagher argues that the CDB and Eximbank now provide more loans to Latin American governments than the World Bank and Inter-American Development Bank, and more loans to Asia than the World Bank and Asian Development Bank. ${ }^{8}$

In late 2013 the New Silk Road and Maritime Silk Road were unveiled, both under the umbrella of the Silk Road Fund (a new fund to provide resources for infrastructure projects to connect countries throughout Asia), with the aim of building two trade and infrastructure networks connecting East Asia with Europe. As of late 2014 the Chinese government announced that it planned to create an additional " $\$ 16.3$ billion fund . . . to build and expand railways, roads, and pipelines in Chinese provinces that are part of the planned Silk Road Economic Belt," to be overseen by the CDB and other Chinese policy banks. 9

The New Development Bank (NDB, better known as the "BRICS Development Bank") was first discussed in 2012, with a resolution formally approved by China, Brazil, Russia, India, and South Africa in 2013. The initial mandate of the NDB is 
to provide loans, equity participation guarantees, and other financial instruments to fund infrastructure and sustainable development projects throughout the developing world. The NDB has an initial authorized capital of $\$ 100$ billion, and an initial subscribed (paid-in and callable) capital of $\$ 50$ billion. Also, in a direct effort to counter the influence of the IMF, the NDB has a Contingency Reserve Arrangement (CRA) of $\$ 100$ billion. In sum, China will provide $\$ 41$ billion toward the initial authorized capital for the CRA, with Russia, Brazil, and India each providing \$18 billion, and South Africa providing \$5 billion. Other developing countries may be invited to join and subscribe capital to the NDB, but China's leading role is ensured by its financial strength (notably, the \$3.8 trillion in foreign exchange reserves) and the proposed location of the NDB headquarters in Shanghai.

The Asian Infrastructure Investment Bank (AIIB) was announced in October 2013, officially as a response to the need for additional development finance for infrastructure investments across Asia. In October 2014, twenty-one countries signed onto the AIIB as founding members, including close American allies New Zealand, Singapore, and Thailand. Other key U.S. allies initially held off (Australia, South Korea, European countries), largely due to Washington's pressure. Since October 2014, however, an additional thirty-six members have joined, including twenty nonregional members, with the largest cascade occurring after the United Kingdom applied for membership in March 2015. ${ }^{10}$

The AIIB has an authorized capital of $\$ 100$ billion, with an initial subscribed capital of $\$ 50$ billion and a paid-in ratio of 20 percent. The governance rules are still under discussion. Beijing hopes to have the articles of agreement by the end of summer 2015 with the AIIB starting operations at the end of the year. One of the issues not yet resolved is how the voting shares will be allocated among the now fifty-seven founding members. In October 2014 these founding countries agreed on a proposal that would make a combination of GDP and purchasing power parity the basic determining factor of voting shares. They also agreed that there would be different arrangements for Asian and non-Asian members, with one option to have Asian members hold 75 percent of the total voting shares. This formula promises to gives China the lion's share of the voting rights, with the remaining 25 percent going to non-Asian members. These rules, however, have not yet been codified. One of the reasons many states rushed to join the AIIB by the April 15 deadline for founding members was to preserve their opportunity to help shape those rules. ${ }^{11}$ Furthermore, the Chinese finance minister announced 
that the AIIB will have a board of governors, a board of directors, and a president (much like the World Bank). The board of directors, however, will not be in residence at the headquarters in Beijing, which may result in considerable autonomy for the AIIB's management.

\section{China's Intentions: Contested Multilateralism?}

Whether or not China's bold moves to create new development institutions represent contested multilateralism depends greatly on China's intentions. Conventional wisdom holds that Chinese development lending is driven primarily by the search for greater access to natural resources in order to sustain China's economic growth. According to the few existing empirical studies of Chinese development financing, over 40 percent of all Chinese lending is in the energy and natural resources sector, including land acquisitions for agricultural production and export. ${ }^{12}$ There is also speculation that the recent slowdown in China's economic growth to single digits is influencing some Chinese policymakers to see aid as a way to create export markets, jobs abroad for Chinese workers, and new contracts for Chinese construction and manufacturing firms. For example, according to Alvin Cheng-Hin Lim, "the employment opportunities created by the 'Belt and Road' initiatives will be needed for the 15 million students who are expected to graduate from universities and middle schools and join the workforce in 2015, as well as the 3 million surplus rural laborers who are also expected to join these students in the employment market." ${ }^{13}$

China also desires to gain international influence and prestige. On the one hand, it is striving to accumulate hard power, by challenging the role of the U.S. dollar. The rise of Asian-based multilateral institutions, as well as increased lending by China's policy banks, may create an increased role for the yuan in international exchange and outlets for China's current account surplus, despite its recent devaluation. In early March 2015, Beijing also asked the IMF to include the yuan in its basket of reserve currencies. On the other hand, China is also trying to build its soft power via increased development financing. In addition to providing low-concession loans, it has established numerous Confucian Institutes to spread awareness of Chinese culture and language, built friendship hospitals, and sponsored numerous educational exchanges with countries in Africa, Latin America, and South Asia. China has also established cooperative agreements with existing multilateral development banks. In 2014 it announced the formation of the "Africa Growing Together Fund," a \$2 billion investment vehicle created in partnership with the African Development Bank. President Xi 
Jinping's first foreign trip as head of state in March 2013 included stops in Africa to signal China's growing commitment to building Sino-African cooperation.

China's actions may also be seen as motivated by its desire to redress the aforementioned failure of IMF reform efforts and its frustration with the World Bank's incremental voting reforms. Beijing feels that its current level of voice and influence in both institutions is not adequate to its perceived status and economic weight in the world. ${ }^{14}$ China controls 6.47 percent of votes in the Asian Development Bank (ADB), 5.17 percent in the World Bank, and only 3.81 percent in the IMF. ${ }^{15}$ By contrast, Japan and the United States each hold 15.6 percent of the voting shares at the $\mathrm{ADB}$, and Washington controls 17.3 percent and 16.75 percent of the votes at the World Bank and IMF, respectively. On paper, the sheer volume of Chinese lending appears to be a viable challenge to the current structures and rules of global economic governance, and to the influence that the status quo powers (especially the United States) exercise through these traditional institutions.

The key question is whether China truly wants to be a revisionist power that will rewrite the rules of global finance and development, or whether it wants to be a leader that works largely within a preexisting set of institutions, rules, and norms. The irony of the latter, of course, is that it is exactly what the United States has been demanding. Yet the U.S. Congress has for five years blocked governance and quota subscription reforms at the IMF, which both the Fund Executive Board and the Obama administration lobbied for in 2010. This has arguably led to the conditions under which the creation of alternative institutions by China was nearly inevitable. ${ }^{16}$ Yet this outcome does not ipso facto mean that the new Chinese-led development banks will compete against or crowd out existing institutions. It may very well be that they complement or work in parallel with U.S.-led institutions in a new, post-hegemonic era.

\section{Continuity or Change in Global Development GOVERNANCE?}

Will the rise of Chinese aid promote continuity, incremental change (adaptation), or deeper structural and ideational change in the current global governance of international development? There are a few simple facts that belie the notion that China's policy banks, the NDB and AIIB, will produce imminent or deeper change to the cast of players, power dynamics, and paradigms that constitute the global 
economic governance system. Incremental change is the more likely outcome, at least in the near (ten to twenty year) future.

First, a simple market analysis indicates that the need for infrastructure investment far exceeds the current resources offered by existing multilateral development banks, leaving ample space for the NDB and AIIB to move in without crowding out existing lenders. An oft-cited 2009 ADB report estimates that infrastructure investment needs between 2010 and 2020 will reach $\$ 8$ trillion globally, 68 percent of which would be for new capacity, including electricity ( 51 percent), roads (29 percent), and telecommunications (13 percent). ${ }^{17} \mathrm{~A}$ similar study by Amar Bhattacharya and Mattia Romani found a "deficit of investment [in infrastructure] of up to around US\$1 trillion annually . . . beyond what is currently likely to be financed." ${ }^{18}$ In launching the AIIB, the Chinese government estimated that $\$ 730$ billion would be needed annually between 2015 and 2020 to fund infrastructure spending in Asia. This far exceeds the $\$ 100$ billion in authorized capital that the AIIB expects to have by the end of 2015. In turn, the ADB, World Bank, and the IMF publicly welcomed the creation of the AIIB early in 2014 and emphasized the potential for collaboration between the multilateral development banks to fill systemic gaps in infrastructure funding.

Indeed, even with the addition of infrastructure lending by the AIIB, NDB, and $\mathrm{CDB}$, there is plenty of space in terms of absolute market share for the World Bank and ADB because these newer institutions do not-and likely will not in the next fifteen years-have sufficient capital to meet the overwhelming demand for infrastructure investments, particularly in low-income and fragile states where high risk deters private investment. The AIIB's focus on Asia also leaves significant market gaps in other regions. For example, a 2009 report by the World Bank estimated that Africa requires $\$ 93$ billion per year in official development aid to fill the infrastructure needs left by the lack of national budget resources and private capital. ${ }^{19}$

Moreover, the ADB and the World Bank both work in many other sectors besides infrastructure and enjoy much higher levels of subscribed capital. As of 2013, the ADB had subscribed capital (both paid-in and callable) of just over $\$ 160$ billion and the World Bank had \$223 billion. The other major multilateral development banks (African Development Bank, European Bank for Reconstruction and Development, and Inter-American Development Bank) have a combined subscribed capital of over $\$ 300$ billion. The ADB and the World Bank also enjoy AAA long-term issuer credit ratings, which give both institutions excellent access 
to international capital markets to leverage further resources for large-scale projects. By contrast, the NDB and AIIB may face challenges in establishing "governance structures and decision-making systems having a high degree of transparency, integrity, and independence from political influence in making lending decisions ${ }^{\prime 20}$ that will translate into similar international credit ratings and the ability to access private capital markets. While some believe China's role will help maintain the AIIB's credit rating, others argue that the "AIIB may have to pay dearly to get financing from international capital markets because most of its member countries have a B grade credit rating." ${ }^{21}$

The Obama administration has expressed concerns that the NDB and AIIB pose threats to the current international development regime because they may not uphold global norms of transparency, accountability, and environmental and labor standards. China has allayed some of these fears by hiring several retired World Bank officials to help design the governance rules for the AIIB. ${ }^{22}$ The interim head of the AIIB, Jin Liqun, worked at the World Bank and ADB and is reported to be recruiting staff internationally. ${ }^{23}$ More critically, in the weeks leading up to the April 15 deadline for membership application, China also offered to forego veto power in the AIIB in order to entice such key European states as the United Kingdom, France, and Germany to join. These are all signals of China's intentions to exercise strategic restraint ${ }^{24}$ in order to attract other major states into its new institutions. While the AIIB may pose a direct threat to U.S. influence over international development, its current membership and rules signal continuity with current development principles and operating standards.

What change might we see in the existing players, powers, and paradigms that govern international development aid? Normatively speaking, the incremental change in governance structures and competition from Chinese-led multilateral institutions may be a very healthy incentive for the World Bank and ADB, making them more attuned to the demand for infrastructure from borrower countries. In fact, both institutions have increased infrastructural lending over the past decade. Yet reforming the business models of the World Bank and ADB is not an easy task. Organizational incentives, sensitive to decades of external criticism of their project management and oversight, are not aligned with increased infrastructure lending due to the higher corruption, environmental, and social risks inherent to this sector. Existing lending in the infrastructure sector has also tended to be pro-cyclical, decreasing during crises-just when aid monies are most needed to offset declining private capital and national budget resources. ${ }^{25}$ Some critics are 
also concerned that the efforts of multilateral development banks to attract borrower demand for infrastructure projects in the face of Chinese competition may lead to weakened conditions with respect to procurement processes and environmental and social safeguard mechanisms. However, there is little evidence of this to date, whereas the CDB and AIIB have made a concerted effort to demonstrate that they are moving toward stronger compliance with global norms on these fronts. A race to the bottom does not appear to be inevitable.

More promising are the opportunities for the World Bank and ADB to leverage their comparative advantage in areas that complement loans, such as investment guarantees and procurement oversight-areas in which the NDB and AIIB will have little experience. More critically, the World Bank and ADB are far better positioned to provide support for the governance and institutional reforms needed to turn investment in infrastructure into sustainable and equitable growth. Finally, the World Bank is especially experienced at managing global funds. This all indicates that, if properly supported through inclusive policies, the new multilateral development banks could provide much needed resources to expand global cooperative efforts, thereby complementing and enhancing the relevance and legitimacy of the World Bank and ADB rather than contributing to their slow decline. If there is competition, it is more likely to be between the NDB and AIIB than between the new and old institutions. ${ }^{26}$

\section{Conclusion}

Three issues may shape whether the rise of Chinese development financing will lead to incremental or deeper changes in global development governance. First, growth in the subscribed capital and expenditures of these new funds will depend on the sustained material power (that is, the economic growth) of China. Growth has slowed, the Chinese stock market has shown recent signs of volatility, and overall China is facing numerous challenges associated with rapid economic development, including air pollution, intensified urbanization, burgeoning public and private debt, and looming problems of under- and nonperforming loans in the banking sector and of currency devaluation. China will also have to cope with the costs of providing for an aging population and military modernization. ${ }^{27}$ China may be a major new player in development, but how much of a role it plays may be contingent on its sustained power. 
Second, China's development model emphasizes cooperation and investment primarily in infrastructure. However, it is difficult to determine the long-term demand for infrastructure aid provided by China through its various institutions. It is possible, as some argue, that the AIIB could become the financier of first resort for coal power plants and other controversial energy projects. This scenario assumes that such projects would first be approved by the AIIB, which now has many new members that would likely oppose them.

There is also evidence that the current popularity (and thus demand) for Chinese development financing is waning due to concerns over the impact of Chinese aid. So-called cooperative agreements, especially in Africa, are reached via obsolescent bargains in which China clearly has the upper hand, leading in some cases to land grabs and other appropriations of valuable resources. Developing countries, while thankful for low-cost infrastructure funds, are becoming disenchanted with the Chinese practice of importing labor and equipment rather than providing local jobs. In some areas of Africa, China is flooding markets with cheap goods that drive out local businesses. Chinese development has also increased public debt in several countries, such as Ghana, since nearly all of China's aid comes in the form of loans.

Overall, however, attitudes toward Chinese aid in Africa and South Asia are still largely positive. For example, in spring 2014 the Pew Research Center's Global Attitudes Survey found mostly favorable views of China across the African continent, except in South Africa, where the favorable rate was only 45 percent. (This may have some implications for the viability of the NDB and the willingness of South Africa to agree to any increase in China's subscribed capital to the NDB.) At the same time, the Pew survey also found that the belief that "China's economy helps Africa" has diminished since 2007, with the highest declines in the countries that receive large amounts of Chinese aid (Nigeria, Tanzania, Ghana, and South Africa). ${ }^{28}$

Third, the future will likely be shaped by how current major powers respond to unfolding events. Will the United States be able to exercise strategic restraint and allow China to assume a leadership role in international development financing? As the stampede to join the AIIB shows, Washington's allies are facing long-term economic woes and looking east to diversify their commercial partnerships. For many countries, including Australia and South Korea, China now represents their largest trading partner and potentially the largest source of foreign direct investment. 
Any threat that the new China-led banks may pose to U.S.-dominated governance may be a threat of the United States' own making. By failing to enact meaningful reforms, by trying to bully allies into acting against their economic interests, and by accusing the new development banks of falling short of good governance standards, the United States is exhibiting what Larry Summers calls "gross hypocrisy." ${ }^{29}$ By opting out of the conversations that shape the governance of the AIIB, Washington will lose not only control but also influence.

It is ironic that those actors most ardently using their power to defend continuity in governance structures may in fact be creating the conditions that compel new players to produce deeper change. A more prudent policy would be one of accommodation and inclusion, granting more voice and influence to rising powers within extant institutions, and thereby creating space for new ideas on governing development.

\section{NOTES}

${ }^{1}$ Manuella Moschella and Catherine Weaver, eds., Handbook of Global Economic Governance (London: Routledge Press, 2014).

2 Julia C. Morse and Robert O. Keohane, “Contested Multilateralism," Review of International Organizations 9, no. 4 (2014), pp. 385-412.

${ }^{3}$ Charles Wolf, Jr., Xiao Wang, and Eric Warner, China's Foreign Aid and Government-Sponsored Investment Activities: Scale, Content, Destinations, and Implications (Santa Monica, Calif.: RAND Corporation, 2013), p. xxi.

${ }^{4}$ Ibid., p. xiii.

${ }^{5}$ Erica Downs, Inside China, Inc: China Development Bank's Cross-Border Energy Deals (Washington, D.C.: Brookings Institution, 2011), p. 6.

${ }^{6}$ See also Henry Sanderson and Michael Forsythe, China's Superbank: Debt, Oil and Influence-How China Development Bank is Rewriting the Rules of Finance (Singapore: John Wiley \& Sons Singapore, 2013).

7 Downs, Inside China, Inc.

${ }^{8}$ Kevin P. Gallagher, "Obama Abandons Allies on China’s Marshall Plan," Globalist, March 18, 2015.

9 "China Planning US\$16.3b New Silk Road Fund," South China Morning Post, November 5, 2014. See also Alvin Cheng-Hin Lim, “Africa and China's $21{ }^{\text {st }}$ Century Maritime Silk Road," Asia-Pacific Journal 13, no. 10 (2015).

${ }^{10}$ Even Taiwan applied in late March, although its application was quickly turned down. North Korea was also rejected.

${ }^{11}$ More bluntly, however, economic interests also clearly played a role in European states' decision to ignore Washington and join the AIIB.

${ }^{12}$ Wolf et al., China's Foreign Aid and Government-Sponsored Investment Activities.

${ }^{13}$ Lim, "Africa and China's $21{ }^{\text {st }}$ Century Maritime Silk Road."

${ }^{14}$ The World Bank increased China's voting shares in 2010, making it the third largest shareholder. However, there is still some disgruntlement that the 5 percent does not adequately reflect China's (and other emerging market economies') weight in the world economy.

15 These figures draw on the 2014 annual reports of the ADB, IBRD and IMF.

${ }^{16}$ Daniel W. Drezner, "Anatomy of a Whole-of-Government Foreign Policy Failure: The Asian Infrastructure Development Bank is Proceeding Apace, Despite U.S. Efforts to Stop It," Washington Post, March 27, 2015. See also David Bosco, "What Washington Did Wrong (and Didn't Do Wrong) on the AIIB," Pointsoforder.com, April 3, 2015.

17 Reuters, "ADB will be 'very happy' to work with China's Asia Infrastructure Bank," May 2, 2014, www. reuters.com/article/2014/05/02/kazakhstan-adb-banking-idUSL6NoNO1ZG20140502. 
18 Amar Bhattacharya and Mattia Romani, "Meeting the Infrastructure Challenge: The Case for a New Development Bank" (GGGI, G-24 and LSE, March 2013). See also Stephany Griffith-Jones, "A BRICS Development Bank: A Dream Coming True?” UNCTAD Discussion Paper No. 215, March 2014.

19 Vivien Foster and Cecilia Briceno-Garmendia, eds., Africa's Infrastructure: A Time for Transformation (Washington, D.C.: World Bank, 2010), p. 1.

20 "China Uses Development Bank Push to Become Banker to Emerging Markets," Caixin Online, December 2, 2014

21 Ibid.

22 "China Forgoes Veto Power at New Bank to Win Key European Nations' Support," Wall Street Journal, March 23, 2015.

${ }^{23}$ Jane Perlez, "Stampede to Join China's Development Bank Stuns Even Its Founder," New York Times, April 2, 2015.

${ }^{24}$ G. John Ikenberry, After Victory: Institutions, Strategic Restraint, and the Rebuilding of Order after Major Wars (Princeton, N.J.: Princeton University Press, 2000).

25 Scott Morris and Madeleine Gleave, "The World Bank at 75," Center for Global Development Policy Paper 058, March 2015. See also Griffith-Jones, "A BRICS Development Bank."

${ }^{26}$ Dan Drezner, “The BRICS have a Bank. What Does That Even Mean?” Washington Post, July 16, 2014.

27 Wolf et al., China's Foreign Aid and Government-Sponsored Investment Activities.

${ }^{28}$ Katie Simmons, "U.S., China compete to woo Africa," Pew Research Center online, August 4, 2014, www.pewresearch.org/fact-tank/2014/08/04/u-s-china-compete-to-woo-africa/.

${ }^{29}$ Lawrence Summers, "Time U.S. Leadership Woke Up to New Economic Era," April 5, 2015, larrysummers.com/2015/04/05/time-us-leadership-woke-up-to-new-economic-era/. 